\title{
Urban Road Transportation in Nigeria From 1960 To 2006: Problems, Prospects And Challenges. Ogunbodede E. F**
}

\begin{abstract}
The nature of urban road transportation problems in Nigeria as at today can best be appreciated by looking at the trend of its development since Nigeria came into existence. Thus, this paper, attempt a cursory review of urban road transportation system in Nigeria from 1960 to 2006 (a period of 46 years). The paper adopts exploratory method of research to examine and discuss relevant issues of interest in the history of Nigeria road transport system in six sections. It was discovered that urban road transport system in Nigeria is inefficient and grossly inadequate even after 46 years of becoming independent from Colonial Rule. The paper suggested the construction of more motor-able roads within cities in order to increase the network; encourage increased public and private participation in the provision of transport services within cities and inter-cities transport system. The adoption of motorcycle as public mode of transportation in cities should be institutionalized since the users are constrained to use this means of transportation in the absence of alternative. However, policies guiding the regulations and use of this mode should be formulated and monitored so that its use would not impact negatively on the commuters' mobility rights and lives. Similarly, government should provide enabling environment that would guaranty efficient and adequate movement of vehicles in cities.
\end{abstract}

\section{Key words: commuting distance, Tokunbo, commuters, Kabukabu, Okada}

\section{Introduction}

What is now regarded as the
Nigerian Nation came into existence in 1914, when the two protectorates of Northern and Southern Nigeria were amalgamated under the Governor-Generalship of Sir Frederick Lugard. The country became independent in 1960 and a republic in 1963 after more than half a century of British rule. According to Udo (1978), "the relics of British rule have since remained in every aspect of Nigeria life". Prominent of such relics are transport, education and the pattern of governance in the country.

In 1963 and 1991, the population of Nigeria stood at 56 and 88.9 millions respectively with a land area of about $923,773 \mathrm{~km}^{2}$. According to Ogunsanya (1988), Nigeria had a rate of urbanization that was ranked as one of the highest in the world. Available statistics, as at that time, indicated that by 1988 , more than $30 \%$ of the country's population lived in urban centers of 100,000 and above. It was also estimated that by the year 2000, the proportion of population living in cities would have increased to $50 \%$ from its 1990 rate of $35 \%$. This shows that a major feature of Nigeria population structure is an increasing tendency for people to concentrate in the urban area. This is because the major area of settlement change and development is the city. Since most of the urban areas remained the major points of administrative, industrial, commercial, educational, social and recreational centers of the country. The multi-functions performed by these cities make them to generate and attract large number of intra and inter-urban road traffic.

The pattern of Nigerian urbanization has many implications on various areas of the country including determining the areas of road traffic origination and destination. Associated with these implications are various urban problems such as unemployment, housing problems, environmental pollution, transportation problems and general inadequacy of infrastructural facilities. This study however is interested in the aspect of urban transportation and its growth over a period of not less than 45 years in the country. Urban transport system can be viewed from two major areas, which are the intra-urban and interurban transport systems. Intra-urban system as it existed today in Nigeria is

*Department Of Geography And Planning Sciences, Adekunle Ajasin University, Akungba-Akoko, Ondo

State,Nigeria.bodede_f@yahoo.co.uk 
largely owned by private sector except Lagos and Port Harcourt where public sector also participates along side with the private sector. Until recently too, interurban transport system was wholly dominated by private owners.

Urban mobility problems had been on the increase since independence. This is due to rapid increase in population in urban areas, which is not matched with growth in transport facilities such as road network, transport complimentary facilities, transport services and traffic management techniques. Thus urban transport problems have increasingly been noted since 1960, to be characterized by inadequate and inefficient services, long waiting time at bus stop, environmental pollution, traffic congestions, and bad roads, shortage of vehicles and the use of motorcycle as a means of urban passenger transport system.

Transportation problems as enumerated above have attracted several government commissioned studies like that of Max Lock, Master Plan for Gombe and Minna; Dar Al-Handasah for Okene, Gombe and Offa; Lea-Deleuw-Osot and Sigmud Grava for Lagos Metropolis. All these studies were intense and were carried out in the country between 1974 and 1978 for the major urban centers in the country as noted by Ogunsanya (1993). There were also non-commissioned studies in the area of transport research work conducted by the academic staff of universities and polytechnic and their students. According to Ogunsanya (1993), the studies are multi-various in nature and multi dimensional in focus depending on the scholar's discipline and their special area of interest.

The nature of urban public transport problems in Nigeria as at today can best be appreciated by looking at the trend of its development since Nigeria came into existence. In this paper, therefore, a cursory attempt was made to review urban public transport system in Nigeria from 1960 to 2006, a period of 46 years.

\section{Methods of Study and Organization of the Paper}

This paper adopts exploratory method of research to examine and discuss relevant issues of interest in the history of Nigeria transport system. Thus, the paper reviews existing literature on urban transportation system of Nigeria. Because of the nature of the study (macro), the writer relies on published documents in the area of public transport system using commissioned studies, non-commissioned studies and published works from various sources. Some of these secondary sources are narrow in perspective and scope but they serve as useful materials for researchers wanting to embark on a macro-study. Others include library books, data from Federal office of statistics and articles from learned journals.

The paper is organized in six sections apart from the introduction and method of study. These are:

Road network development between 1960 and 2006

Socio-economic setting which influence urban transport system.

Government policies in the area of urban public transport system.

Constraints to public transport system development in Nigeria.

suggestions for improvement

Conclusion.

\section{Road Network Development Between 1960 and 2006.}

The history of road transport development in Nigeria dated back to the period before 1910 when the existing bush paths were developed into motorable routes. According to Standford Research Institute (1963), the growth of road transport in Nigeria was a later development, which did not evolve through the stage of animal-drawn carts. According to this Institute, roads were not developed until the advent of motor vehicles in the 1920s and 1930s. The end of Second World War (1945) actually marked the period when the country was served with adequate network of all season roads for lorry and passenger car traffic. According to Onakomaiya (1978), the roads were designed to serve two major objectives. First, they were meant to extend the commercial hinterlands opened up by the government railways by linking up the nearest urban centers with the major railway stations. The second was to 
reduce the strains thrown on the inland provinces in the provision of porters for the British Colonial Officers. The initial growth of road network was slowed down by the financial and labor constraints.

However, the total length of road constructed and maintained by the government and native authorities rose to about $51,000 \mathrm{~km}$ in 1946 and 74,000km in 1960 (Onokomaiya, 1978). The need to open up the economic and settlement frontiers of the country was the major factor that influenced road network development in Nigeria. This began with the introduction of feeder road services to the Nigerian Railways to link the major railway stations along the Lagos-Kano line with the neighboring settlements, thereby increasing the supply of export products such as cocoa, palm produce, cotton and groundnuts that were moved to the ports by the railways and helping the rural settlements realize their productive potentials. As at 1960, roads linked all parts, although the concentration of roads is much heavier in the two Southern Regions than in the more sparsely populated Northern Region. The roads in Nigeria were classified into three (3) groups. Federal Roads or Trunk A $-8,800$ kms $(5,500 \mathrm{mls})$, this represented the skeleton on which the country's road system was built. This trunk represented the main North-South arteries and five East-West arteries. The Trunk B roads, of which there were $7,360 \mathrm{kms}(4,600 \mathrm{mls})$, connected the provincial network with the skeleton trunk A road system. Provincial roads of which there were $57,480 \mathrm{kms}$ $(35,925 \mathrm{mls})$ form the main network linking up with other trunk roads in the country. Table 1 shows Nigeria roads by classification, surfacing and at regional level as at 1960.

As at 1960, the percentage of trunk A roads tarred to the total road surface in Nigeria was highest in the Western part of Nigeria with $82 \%$ followed by Eastern region with $30 \%$. However, Lagos, which acted as the Federal Capital had the entire surface tarred. Similarly, $98 \%$ of trunk B roads in the Western region was tarred, $34 \%$ of that of Eastern region was tarred while $19 \%$ of that of Northern region was tarred.
The period between 1976 and 1970 witnessed no growth in road network because of the Nigerian civil war, which took place during that period. This period and the financial resources of the country were devoted to the execution of the Nigerian civil war. The period between 1971 and 1975 coincided with the policy of the Nigerian Government to rehabilitate the war torn areas. Thus, money was earmarked for the reconstruction and rehabilitation of the road network in the Eastern part of Nigeria, which were largely damaged during the civil war. Similarly, in other parts of the country, a large proportion of roads were taken over from the state government by the federal government for construction and completion. The Federal Government took this step because of the advantages derivable from the construction of more road networks. This advantages include fostering internal trade between areas of the country, that were not accessible by any other mode of transport, and the development of natural resources of the remote areas of the country. The rehabilitation and construction of new roads were also undertaken in other to raise the standard of living of the Easterners because of the negative effect of war in that region. Other reasons for the take-over of some road networks construction by the federal government according to Onakomaiya (1978) was the reduction in road traffic accidents, which had been achieved on many of the roads because of their improved designs in terms of width and strength.

Since 1975 and through the $3^{\text {rd }}$ and $4^{\text {th }}$ Development plans and rolling plans, the Federal Government used road construction as instrument to gain political points because its structures were better appreciated aesthetically and spatially. Thus, the military and civilian governments at centre, state and local government levels embarked on many road constructions that culminated in the present dense nature of Nigeria's road network.

The issue of state creation, which had been on since 1963 when Mid-West was created from Western Region until 1996 when we had 36 states, made all the 
State Headquarters to be isolated for developmental purposes. Thus, the State Headquarters became growth pole/foci point from where a lot of infrastructural development gained priority. The State Headquarters created in 1967 and 1976 were given mobilization money. Certain percentage of the mobilization money was expended on compensation for houses which were demolished and used for construction of dual carriage way (Ogunbodede, 2004).

The administrative system of Nigeria has changed many times since the creation of the country. The changes were due to a number of factors among which were those connected with the social systems, administrative convenience, spatial problems, economic considerations, official policies such as indirect rule, military and democratic rules. Table 2 shows the administrative structure of Nigeria since 1900 until 2006. The creation of States, which was intense, therefore had many implications to transport facilities as well as the traffic management techniques adopted in the city centers. Thus, as the States increased, the administrative headquarters also increased thereby influencing roads, that were rehabilitated and constructed. Thus by 1996 , road networks in 36 major urban centers in Nigeria had undergone series of transformation in terms of construction and reconstruction.

Similarly, commuting distance within the cities continued to increase because of rapid growth in population, housing and area extent. For example, commuting distance of Akure increased from $5.2 \mathrm{~km}$ in 1966 to $6.4 \mathrm{~km}$ in 1976 , to $10.5 \mathrm{~km}$ in 1986 , $13 \mathrm{kms}$ in 1996 and19kms in 2006 for the major artery (Ogunbodede, 2006). Similarly, the commuting distance in the city of Lagos increased from $20 \mathrm{~km}$ in 1970 to $35 \mathrm{~km}$ in 1995 while that of Kaduna increased from $6 \mathrm{~km}$ to $10 \mathrm{~km}$ during the same period (Ikya, 1993). The increase in commuting distance has impact on trip generation, attraction and the public transport services that facilitated movement from one point to another.

\section{Socio-Economic Setting of Urban Transport System 1960 - 2006.}

Road is the major mode of transport system in Nigeria. Other means of intra-urban and inter-urban transport system are the use of inland waterways and rail transport which are of course limited to a very few urban centers with peculiar terrain (water) in Nigeria. Even in terms of haulage of goods, the advent of motor vehicles revolutionized transport and constituted a challenge to the railroads. According to Standford Research Institute (1963), Road transport as at 1953 was carrying $50 \%$ of the total ten-miles of freight in Nigeria and by 1960; the proportion had increased to $62 \%$ while the total traffic carried by all forms of transport had more than doubled.

Studies in the area of urban transportation confirmed that more than $75 \%$ of population in cities depended on public transport while about 25\% depended on private transport system (Ogunbodede, 1990; Ogunjumo, 1986; Okpala 1981 and Mrakpor, 1986). The socio-economic variables of Nigerians contributed in no small measure to this pattern. Public transport system, which is an aspect of the country's transport sector, had all along been in the hands and control of Nigerian private entrepreneurs. Thus, the private owners dictated largely the modus operandi of the nations public transport system. In the early 1960 s, the macro-economic indicators, which are yardsticks for measuring all aspects of the growth of Nigeria's economy, were consistently positive. This was because the nation depended much on agricultural products for its foreign exchange earnings and a low proportion of the population were engaged in white-collar jobs. During this period, a number of private individuals owned private vehicles, which they used for both intra and inter-urban movements. The use of public transport for intra-urban movement purposes were largely concentrated in large cities like Lagos and Ibadan while commuters contend with the use of trekking within smaller towns as at 1960 . The situation however changed drastically today, as the commuting distances in towns and cities have increased. According to Ogunsanya 
(1993), there were 6,822 vehicles in Nigeria by 1946 made up of 4,702 relicensed and 2115 new ones. The figures soared to 20,440 by 1950 made up of 14,200 re-licensed and 6,240 new ones. The vehicle stock grew gradually from this time up to 1970 when it shot up astronomically. This period coincided with the period of rapid urbanization although a period of doldrums was experienced during the period when Nigerian was engulfed in the civil war (1966-1970). After 1970, it became clear that there was going to be an automobile explosion in the cities of Nigeria. This is because vehicle stock rose sharply from a modest 100,268 vehicles in 1970 to $1,009,797$ in 1977 . Unfortunately, the roads constructed then were unable to accommodate the increased vehicle at such a rapid speed. Thus, the problem of immobility in Nigeria cities started to unfold itself.

The nation, beginning from 1979, plunged into an abrupt economic depression, which was part of a global one. Adeyemo (1995), reporting on the very low to negative growth rates of key macro-economic indicators during this period explained that the country on the external side witnessed negative account balance while internal imbalances were manifested in the high inflation rate, high level of unemployment and low level of capacity utilization. This situation led to the adoption of structural adjustment policy (SAP). The SAP created more problems than solution. This was done because the choice of instrument and the implementation created side effects that inhibited sectoral growth particularly in the transport sector, which was not only capital intensive but also import dependent. The exchange rate continued to fall. For example, it fell from $\$ 1.00$ to $\$ 1.5$ in $1993 ; \$ 1.00$ to $\$ 88.00$ in 1994 , $\$ 1.00$ to $\$ 115.0$ in year 2000 and $\$ 1.00$ to $\# 120$ in year 2005. It became difficult to import vehicles and spare parts and when they were imported at all cost, they were done at a very prohibited cost. Similarly, the cost of locally manufactured vehicles went up and vehicle-manufacturing companies closed up e.g. Volkswagen of Nigeria (VON). The period between 1985 and 1998 was particularly difficult for
Nigerians as the standard of living became very low. This was the period when Nigerians could hardly take three meals in a day. Hence buying of vehicles for whatever purposes was not considered as being in the priority. New vehicle registration therefore fell drastically in the country while many old vehicles quit the road. For example, vehicles declined from 700,000 vehicles in $1983 / 84$ to under 500,000 in 1987 . This fall was projected to continue to decline to 350,000 in 1991 (Ogunsanya, 1993). Unfortunately, as the vehicle stock in the country continued to decline, population continued to rise, while disposable income continued to fall. The situation continued to approach crisis stage when government decided to set up a task force to look into urban transportation problems with a view to proffering solutions.

The public, in reacting to the high cost of buying new vehicles, resulted to buying used vehicles (Tokunbo). Thus, used buses, and cars were imported from overseas and people started buying them. According to Federal of Statistics (FOS) 1997, there was a drastic increase in the vehicles registered between 1995 and 1996. The vehicles newly registered dropped from 57,883 in 1994 to 57,471 in 1995 and picked to 97,371 in 1996 while the provisional data for 1997 stood at 1,081,933 (see Table 3) other means by which new vehicles were increased in the country was through Federal Urban Mass Transportation and Government parastatals that acquired vehicles through their annual subventions.

Government Policies in the Area of Urban Road Transport System Development

The Federal Government of Nigeria recognized that the development of road transport is essential to the growth of the economy and for this purpose, $13.1 \%$, $15.8 \%, 19.0 \%$ and $12.7 \%$ of the total gross capital expenditure from 1955 to 1959 was devoted to road transport (See Standford Research Institute, 1963). Since then, the first, second, third and fourth National Development Plans (1960-68; 1970-74; 1975-80) also had more than $25 \%$ of the total allocation to Development Plans devoted to transport sector while allocations to rail was declining. The 
preference of Government to the provision of road transport infrastructures later influenced the provision of transport services not only in the urban centers but as well, as inter urban services.

Initially large private companies dominated the provision of transport services and these were mainly interurban. As at independence, the list of selected Nigerian road transport common carriers were sixteen as listed in Table 4. The vehicles specialized in the haulage of agricultural products, petroleum products, mails and to some extent passengers. Most of the vehicles used are trucks and very few passenger buses. Of the 16 road transport common carriers, ten of them service Lagos and other parts of the country.

Shortly after independence, most towns in the country grew in area extent to a level that trekking within such towns became very inefficient and inadequate. Attempts at increasing the stock of private vehicles to provide transport services for commuters became inevitable. Apart from individual's contribution, the government was also involved in the provision of public transport services. The Nigerian government set up a task force to look into the urban transportation problems and proffer solutions. The task force gave birth to Mass Transit Implementation Committee, which recommended among other things provision of buses, spare-parts and other transport complimentary facilities for Nigerians. The introduction of the Federal Urban Mass Transit Programme (FUMTP) ushered in a number of policies that made the Mass Transit a success. Such policies include monitoring and providing guidelines on Nigeria's urban transport system. It also looked at the aspect of rehabilitation of some locomotive and coaches for the commencement of intra-city rail services, as well as rail terminals and stations within Lagos Metropolis. The policy also ensures the rehabilitation of ferries of the inland waterways as well as providing standard maintenance workshop for all different cadres of middle and high level manpower in the state; similarly, seminars/workshops to review problems relating to urban transportation were largely undertaken. All these policies not withstanding, the mass transit faced many problems.

The management of the state mass transit agencies became deplorable and almost all the state agencies ran at a loss. The urban mass transit, which was conceptualized to provide intra-urban transport services at the point of introduction, could not break even in all the medium sized cities because of lack of threshold population to sustain patronage. This made them to shift their mode of operation from intra-urban services to inter-urban services except, in places like Lagos Port Harcourt where the threshold population that could survive such operations were present. However, the peak periods became chaotic with hold-ups at the slightest inhibition on the road, hence government workers get late to offices and homes in the morning and afternoons respectively.

One-way by which the public responded in beefing up supply of public transport was the use of motorcycle as means of urban transportation. Although, this system was not completely new in Nigeria as Edo, Rivers Akwa-Ibom and Cross River States started its use long time ago because of the riverine terrain nature of their states. The waterlogged nature of the area made the construction of road costly hence; very few areas were actually networked. Apart from this, the use of motorcycle for public transport system was common in the dispersed settlement of Eastern part of the country where it was first accepted as a public mode for interrural and rural-urban movement.

According to Ogunsanya and Galtima (1993) the general acceptability and use of motorcycle for intra-urban mobility in Nigeria started during the Structural Adjustment Policy (SAP) of the government with its very stringent attributes. It can be argued, therefore that since the Federal Urban Mass Transit and Taxi Cabs were unable to provide adequate intra-urban transport services to sustain multi-various urban activities, other smaller transport system (in this case motorcycle) were on ground, which commuters had to adapt and adopt to satisfy intra-urban movement. This was because it was only natural for the people 
to convert their personal motorcycle for public uses in response to reality of commuter's need. Similarly, personal vehicles of some individuals were used for commercial purposes (Kabukabu). The civil servants who engaged in this type of business do it after working hours or before going to work. With time, the "Okada" system survived the test of time, because junior workers who constitute the majority of Okada riders prefer it to public passenger transport system, which had failed to alleviate the intra-urban movement problems of most of the city commuters. It was therefore only natural for the people to convert their personal motorcycle for public commercial transport system to complement the existing public transport system, which was largely inadequate and to generate additional personal income due to the effect of the Structural Adjustment Policy (SAP). Thus, the genesis of the use of motorcycles and private vehicles as a public transport system on a large scale arose out of the economic woes of 1980's.

Constraints to the Development of Public Transport in Nigeria

The general downward in Nigeria nation's economy which was part of the global depression of 1980's affected all sectors in which transport system was one of them. Majority of Nigerians living in cities felt this impact more than those in the rural areas. This was because the commuting distance of people in cities increased considerable than it used to be before 1980 as stated earlier. This example shows that it was becoming increasingly difficult and inefficient to trek in cities because of the area expansion of the city. The glut of 1980 further compounded the mobility problems of commuters since most of the commercial vehicles in cities went off the road because of poor servicing and lack of spare parts. The Structural Adjusted Programmes (SAP) of the federal government further compounded the importation of vehicles and spare parts such that the shortfall in public transport had to be augmented by interested private individuals in different forms.

Rapid urbanization of cities in the country was a continuous process because of the State creation, which had earlier on been mentioned. However, it became a problem when the rate of growth of the urban population exceeded the capacity of the transport infrastructure and services meant to provide solutions to movement in cities. All the cities in Nigeria have no records of immigrants and emigrants into them. The populations of such cities are not known outside the ones given by census, which comes up periodically. Thus, it becomes a problem to plan without figures and facts. Most planning managements that were carried out in urban areas depended on projected figures of population, which also relies on census figures that many international observers regard as being far from the truth because of exaggerations, which were built into them.

Public participation in transport delivery can be said to be profitable, otherwise none of them would continue to provide these services. On the other hand, it has not been so with Government participation. Evidences available from empirical studies carried out (Odeleye, 2004; Ogunsanya, 1995 and Onakomaiya 2002) showed that state mass transits were run at a loss. The reasons include nonchalant attitude to government work by the employees; embezzlement on the part of drivers and conductors, and inadequate response to taking immediate actions on repairs and services of vehicles by government parastatals established for such purposes.

The attitude of some professional drivers also scares private investment in the area of transport service delivery. Some private rich individuals who were interested in investing in public transport system because it was a lucrative business decided not to do so, because most drivers were found to be insincere and economic with the truth. This is because vehicles given to them are often run at a loss whereas; they break even when they run them on their own. These experiences as noted in the past made would-be-investors to leave these areas of investment to the drivers. The drivers on the other hand have no financial wherewithal to buy vehicles except they buy through the hire-purchase system. This however limited the number 
of people going into public transport business.

The role played by the Nigerian Union of Road Transport Workers (NURTW) in allowing investors to invest in public transport system still remain as an obstacle to private individuals. The union, in addition to registration fees also collects different types of daily fees, which reduces and sometimes renders the profit margin of the owner of such vehicle to nothingness. This is because, the driver would buy fuel, engine oil, eat, pay the conductor and himself before thinking of remitting the rest to vehicle owners. Thus, it pays the professional drivers to invest in public transport system than private investor who will still need to hire the services of a professional driver.

Suggestions for Improvement

Since there are problems in the area of urban road transportation system in Nigeria in the last 46 years, it is only logical to make some suggestions that would assist to alleviate some of these problems. First and foremost is that the government should construct more motorable roads within cities in order to increase the network. Once these infrastructures are provided, the government should encourage increased public and private participation in the provision of transport services within cities and those that would link cities. A way of doing this for the private sectors is for the government to buy "Government assisted small buses" and distribute to drivers who can guarantee a minimum collateral securities to secure one. Others should be encouraged to form cooperative unions through which they can borrow money to buy vehicles. Similarly, the daily fees collected by the National Union of Road Transport Workers (NURTW) should also form a common purse through which bonafide members of theirs can borrow money to buy vehicles.

Government should also as a matter of urgency, undertake macro economic policies that would turn the economy round during this democratic era. Once this is done, the foreign exchange through the market forces will make the naira to appreciate. If the naira appreciates, importation of vehicles and spare parts will become cheaper. Thus, more vehicles would be bought, and more spare parts would be available to make life span of vehicles to last. By so doing, enough vehicles will be provided for both intra and inter-urban services.

There is no way we can check urbanization of cities, however, with facts and figure, we can maintain a balance between population size, population distribution and the environmental infrastructures. Thus, in this case, government policies in the area of public transport service delivery will be more meaningful and result-oriented once the population of each city and its distribution by land use are known. This type of database is important for planning urban transportation system that would evolve efficient and adequate transportation system for the cities.

\section{Conclusion}

Forty six years in the life span of a nation is not too small to jump into conclusion on how the urban public transport system has faired. However, a trajectory of this sector's development over the last forty-six (46) years of which military ruled for more than 30 years showed that this sector is still a baby of about 10 years old. That been so, one can conclude that transport system in Nigeria is still in its infant level. This is because, Nigerian's intra-urban movement is better described as inefficient and inadequate because of long hours of waiting time at bus stops for intra urban transport services, hold-ups are common in city centers, and rush for few available public transport system are common features during peak periods in Nigerian cities.

With democratic structure in place in the country and improved image of the country abroad, the Eldorado of efficient urban transport service delivery may not be all that too far away in Nigeria. This is because, any moment from now, the macroeconomics of the country is likely to change positively, if more foreign and national investments are witnessed. This will make our naira to appreciate and more vehicles and spare parts would be made available. This will go a long way to change the present trend of public transport inefficiency in cities. 
We must also plan for the future mobility of our urban areas since World Health Organization (WHO, 1993) estimated that the period between 1990 to 2020, the total world population will increase from 5.2 thousand million to about 7.8 thousand million. During this same period, the urban population will double. Since natural increase usually becomes the main reason for sustained growth after the initial migration, then there is need to provide mobility needs for people within cities and to link cities. Similarly, there is need to increase and encourage private participation in the provision of public transport services as mentioned earlier.

The use of motorcycle as public mode of transportation in cities should be institutionalized since the users are constrained to use it in the absence of alternate. However, policies guiding the regulations and use of this mode should be formulated and monitored so that its use would not affect negatively the commuters' mobility problems. Similarly, government should provide enabling environment that would guaranty efficient and adequate movement of vehicles in cities.

\section{References}

Adeyemo, Remi (1995); "Government Policies and Mass Transit in Nigeria" in Enhancing the Sufficiency of Mass Transit Operations in Nigeria - Implications for Cost Recovery (ed) by Bolade and Adeyemo.

Ayeni M.A.O. (1978); "Patterns, Processes and Problems of Urban Development" in Oguntoyinbo, J.S.; O.O. Areola and M.Filani (ed), A Geography of Nigerian Development, Heinemann Nigeria Ltd.

Ayeni M.A.O. (1975); "Some Determinants of The propensity to Interact in an Urban Systems" Nigerian Geograhical Journal. Vol. 18 pp 111-120.

Ikya, S.G. (1993); “The Urban Transportation Problems in Nigeria" in Ikya S.G. (eds) Urban Passenger Transportation in Nigeria. Heinemann (Nigeria), pp, 3-28.

Mrakpor, O.O. (1986); "Public Passenger Transport in Benin City. A Study of Accessibility and Reliability". Unpublished M.Sc Thesis in the Department of Geography and Regional Planning, University of Benin, Benin-City.
Odeleye, J. A (2004) "Rail Option in Urban Transportation" in I. Vandu-Chikolo, A. A. Ogunsanya and A.G. Sumaila (ed) Perspectives on Urban Transportation in Nigeria. Published by Nigeria Institute of Transport Technology NITT. Zaria. Pp156-170 Ogunbodede, E.F. (1990); "Adequacy of Public Transport Services in Akure Metropolis: A Geographical

Ogunbodede, E.F. (2004) "Urban Transport and the Environment" in I. Vandu-Chikolo, A. A. Ogunsanya and A.G. Sumaila (ed) Perspectives on Urban Transportation in Nigeria. Published by Nigeria Institute of Transport Technology NITT. Zaria. Pp101-120 Ogunbodede, E F. (2006) "Movement pattern of Commuters and its Implications forTransportation Planning in Akure". Anyigba Journal of Environmental

Studies. Department of Geography and Planning, Kogi State University, Anyigba. Vol.1 (2) pp 1-16.

Ogunjumo, A. (1986); "The Patterns of Trip Generation at Ile-Ife" in Journal of Nigerian Institute of Town Planners. Vol. Vi and vii pp, $99-114$

Ogunsanya, A.A. (1998); "Moving the Urban Masses: Tow Steps Forward one Backwards" in Dange, M; i.v. Chikolo and A.A. Ogunsanya (ed) Issues in Transport Planning and Management. Published by NITT, Nigeria.

Okpala, D.C.I. (1981); "Urban Traffic Management in Nigeria Cities - The Necessity for Mass Transit Priorities in Transportation" in Nigerian National Development. Proceedings of a National Conference edited by S.O. Onakomaiya and N.F. Ekanem.

Onakomaiya, S.O. (1978); “Overland Transport" in Oguntoyinbo, J.S., O.O. Areola and M., Filani (ed), op. cit.

Onakomaiya, S.O. (2002) "Transport Research and Capacity Building in Nigeria: Ebenezer by a Poor Teacher Turned Professor". Valedictory Lecture at Olabisi Onabanjo University, AgoIwoye.

Standford Research Institute (1961); The Economic Coordination of Transport Development in Nigeria Prepared for Town Planning Committee, National Economic Council Federation of Nigeria, Menlo Park, California.

Udo, R.K., (1978); Geographical Regions of Nigeria. London, Heinemann, $4^{\text {th }}$ edition. 
Table 1: Nigeria Road by Classification in terms of Surfacing and by Region as at 1960.

\begin{tabular}{|c|c|c|c|c|}
\hline & Western region & $\begin{array}{l}\text { Tarred } \\
\text { Roads } \\
(\text { kms) }\end{array}$ & $\begin{array}{l}\text { Total tarred } \\
\text { \& surface } \\
(\mathrm{kms})\end{array}$ & $\begin{array}{l}\% \text { of } \\
\text { roads. } \\
\text { Tarred }\end{array}$ \\
\hline$\overline{\mathrm{i}}$ & Federal (Trunk A) & 1075.2 & 1310.4 & 82 \\
\hline ii & $\begin{array}{l}\text { Regional (Trunk } \\
\text { B) }\end{array}$ & 1576 & 1611.2 & 98 \\
\hline \multirow[t]{3}{*}{ iii } & Others & 577.6 & 16112.0 & 05 \\
\hline & Total & 3228.8 & $19,177.6$ & 17 \\
\hline & Eastern Region & & & \\
\hline $\mathrm{i}$ & Federal (Trunk A) & 792 & 1100.8 & 71 \\
\hline ii & $\begin{array}{l}\text { Regional (Trunk } \\
\text { B) }\end{array}$ & 803.2 & 2356.8 & 34 \\
\hline \multirow[t]{3}{*}{ iii } & Others & 100.8 & $18,984.0$ & 01 \\
\hline & Total & 1696.0 & 22441.6 & 08 \\
\hline & Northern Region & & & \\
\hline $\mathrm{i}$ & Federal (Trunk A) & 1920 & 6411.2 & 30 \\
\hline ii & $\begin{array}{l}\text { Regional (Trunk } \\
\text { B) }\end{array}$ & 640.0 & 3419.2 & 19 \\
\hline \multirow[t]{3}{*}{ iii } & Others & 320.0 & 22169.6 & 02 \\
\hline & Total & 2880.0 & 32000.0 & 09 \\
\hline & Lagos (Fed. Cap.) & & & \\
\hline $\mathrm{i}$ & Federal (Trunk A) & 43.2 & 43.2 & 100 \\
\hline \multirow[t]{3}{*}{ ii } & Others & 158.4 & 214.4 & 74 \\
\hline & Total & 201.6 & 257.6 & 78 \\
\hline & $\begin{array}{l}\text { Nigeria(Total } \\
\text { Raods) }\end{array}$ & & & \\
\hline$\overline{\mathrm{i}}$ & Federal (Trunk A) & 3830.4 & 8865.6 & 43 \\
\hline ii & $\begin{array}{l}\text { Regional (Trunk } \\
\text { B) }\end{array}$ & 3019.2 & 7387.2 & 41 \\
\hline \multirow[t]{2}{*}{ iii } & Others & 1156.8 & 57480.0 & 02 \\
\hline & Total & 8006.4 & 73732.8 & 11 \\
\hline
\end{tabular}

Source: Standford Research Institute, (1963). 
Table 2: Administrative Structure of Nigeria since 1900 till 2007

\begin{tabular}{|l|l|}
\hline Year & Administrative structure \\
\hline 1900 & Effective colonization of the Nigeria area by the British \\
\hline 1906 & Merger of the colony of Lagos with the protectorate of southern Nigeria \\
\hline 1914 & Amalgamation of the Southern and Northern protectorate of Nigeria \\
\hline 1919 & $\begin{array}{l}\text { Merger of parts of the Cameroon with Nigeria under the British trusteeship after the } 1^{\text {st }} \\
\text { World War. }\end{array}$ \\
\hline 1947 & Division of Nigeria into three (3) Regions: East, west and the North \\
\hline 1961 & $\begin{array}{l}\text { Merger of Northern Cameroon with Nigeria and Southern Cameroon with Cameroon under } \\
\text { French trusteeship. }\end{array}$ \\
\hline 1963 & Division into 4 regions (Mid-Western Region created from the Western Region ) \\
\hline 1976 & Division into 12 States from the existing 4 Regions \\
\hline 1989 & Division into 19 States \\
\hline 1991 & Division into 30 States \\
\hline 1996 & Division into 36 States (apart from the Federal Capital,Abuja) \\
\hline
\end{tabular}

Source: Author

Table 3: Newly Registered Motor Vehicles by Type 1994- 1997

\begin{tabular}{|l|l|l|l|l|l|}
\hline & Vehicle types & 1994 & 1995 & 1996 & 1997 \\
\hline i & Saloon Station Wagon & 45,401 & 46,097 & 62,504 & 574,971 \\
\hline ii & $\begin{array}{l}\text { Vans / Pick-up /Kit } \\
\text { Car }\end{array}$ & 3,765 & 897 & 7,742 & 49,022 \\
\hline iii & Lorries/Trunks/Tipper & 593 & 616 & 5,733 & 51,003 \\
\hline iv & Buses & 6,804 & 8,558 & 16,094 & 333,454 \\
\hline v & Tankers & 40 & na & 2,196 & 56,246 \\
\hline vi & Trailers & 468 & 498 & 976 & 17,237 \\
\hline vii & Agric Tractors & 812 & 805 & 2126 & na \\
\hline & Total & 57,883 & 57,471 & 97,317 & $1,081,933$ \\
\hline
\end{tabular}

Source: FOS, 1998 
Table 4: List of Nigerian Road Transport Common Carriers as at 1963

\begin{tabular}{|c|c|c|c|c|}
\hline & $\begin{array}{l}\text { Common Carrier } \\
\text { Transporters }\end{array}$ & No. of Vehicles & Area of Services & Goods Carried \\
\hline 1 & A.F. Karouni Ltd. & 40 vehicles & Kano to Lagos & $\begin{array}{l}\text { Groundnut \& General } \\
\text { Merchandise }\end{array}$ \\
\hline 2 & $\begin{array}{l}\text { Arabs Transport } \\
\text { Ltd. }\end{array}$ & $\begin{array}{l}50 \text { (twenty-ton } \\
\text { truck) }\end{array}$ & $\begin{array}{l}\text { Jos/Maiduguri/Fort } \\
\text { Lamy }\end{array}$ & General Merchandise \\
\hline 3 & Daily Times & $\begin{array}{l}38 \text { (five-tons } \\
\text { trunks) }\end{array}$ & Kano/Kaduna & $\begin{array}{l}\text { Newspaper and } \\
\text { passengers }\end{array}$ \\
\hline 4 & Dantata & 30 trucks & Kano/Zaria & $\begin{array}{l}\text { Groundnut and } \\
\text { general merchandise }\end{array}$ \\
\hline 5 & $\begin{array}{l}\text { Alhaji Mustafa } \\
\text { Marouna }\end{array}$ & 23 trucks & Jos / Maiduguri & $\begin{array}{l}\text { Mail and general } \\
\text { merchandise }\end{array}$ \\
\hline 6 & Constantinedes & 20 trucks & $\begin{array}{l}\text { Malamfashi /Fuutua } \\
\text { / Zaria }\end{array}$ & Groundnut \\
\hline 7 & $\begin{array}{l}\text { Alhaji Ima } \\
\text { Okumora }\end{array}$ & 30 trucks & Kontapora/Zungeru & $\begin{array}{l}\text { Mail and general } \\
\text { merchandise }\end{array}$ \\
\hline 8 & El-Khali & $\begin{array}{l}160 \text { (five ton } \\
\text { trucks) }\end{array}$ & $\begin{array}{l}\text { Lagos / Western } \\
\text { Region }\end{array}$ & $\begin{array}{l}\text { General merchandise, } \\
\text { building materials and } \\
\text { petroleum products }\end{array}$ \\
\hline 9 & $\begin{array}{l}\text { Khali and Dibbo } \\
\text { Transportation Ltd. }\end{array}$ & 70 (ten-ton trucks) & $\begin{array}{l}\text { Lagos and Western } \\
\text { Region }\end{array}$ & $\begin{array}{l}\text { Passenger and } \\
\text { contracts }\end{array}$ \\
\hline 10 & Banks transport & 60 (ten-ton trucks) & $\begin{array}{l}\text { Lagos and Western } \\
\text { Region }\end{array}$ & $\begin{array}{l}\text { General merchandise } \\
\text { and building materials }\end{array}$ \\
\hline 11 & Trans-Arab & 50 (ten-ton trucks) & $\begin{array}{l}\text { Lagos/Western } \\
\text { Region }\end{array}$ & General merchandise \\
\hline 12 & S.M. Arabs & $\begin{array}{l}55 \text { vehicles (ten } \\
\text { ton vehicles) }\end{array}$ & $\begin{array}{l}\text { Lagos/Western } \\
\text { Region }\end{array}$ & $\begin{array}{l}\text { General merchandise } \\
\text { and petroleum } \\
\text { products }\end{array}$ \\
\hline 13 & $\begin{array}{l}\text { Hussain Transp. } \\
\text { Ltd. }\end{array}$ & 72 (five ton trucks) & $\begin{array}{l}\text { Lagos/Western } \\
\text { Region }\end{array}$ & General Cargo \\
\hline 14 & $\begin{array}{l}\text { Ojukwu Transp. } \\
\text { Ltd. }\end{array}$ & $\begin{array}{l}35 \text { (five ton } \\
\text { vehicles) }\end{array}$ & $\begin{array}{l}\text { Lagos/Western } \\
\text { Region }\end{array}$ & General cargo \\
\hline 15 & $\begin{array}{l}\text { Armels Transp. } \\
\text { Ltd. }\end{array}$ & $\begin{array}{l}40 \text { trucks and } 10 \\
\text { passenger buses }\end{array}$ & $\begin{array}{l}\text { Eastern/Western } \\
\text { Region }\end{array}$ & Mail services \\
\hline 16 & Trans Nigeria Ltd. & $\begin{array}{l}35 \text { (six ton cargo } \\
\text { trucks) and } 10 \\
\text { tankers }\end{array}$ & $\begin{array}{l}\text { Lagos/Western } \\
\text { Northern Region }\end{array}$ & General merchandise \\
\hline
\end{tabular}

Source: Standford Research Institute, 1963. 